\title{
A Smart City Service Business Model: Focusing on Transportation Services
}

\author{
JungHoon Kim (1) and Byungsun Yang * \\ Smart Cities Research Center, Korea Institute of Civil Engineering and Building Technology, \\ Goyang-si 10223, Gyeonggi-do, Korea; kimjunghoon@kict.re.kr \\ * Correspondence: bsyang@kict.re.kr
}

check for updates

Citation: Kim, J.; Yang, B. A Smart City Service Business Model: Focusing on Transportation Services. Sustainability 2021, 13, 10832. https:// doi.org/10.3390/su131910832

Academic Editors: Yeong-wha Sawng, Min-Kyu Lee, Suchul Lee and Minseo Kim

Received: 10 August 2021

Accepted: 24 September 2021

Published: 29 September 2021

Publisher's Note: MDPI stays neutral with regard to jurisdictional claims in published maps and institutional affiliations.

Copyright: (c) 2021 by the authors. Licensee MDPI, Basel, Switzerland. This article is an open access article distributed under the terms and conditions of the Creative Commons Attribution (CC BY) license (https:// creativecommons.org/licenses/by/ $4.0 /)$.

\begin{abstract}
Most cities have adopted smart city services to solve urban problems. However, an examination of their operations reveals that many of these services have either been discontinued or have failed to advance further since they were not profitable. Therefore, this study reviews and proposes the business models of smart city services at a fundamental level. It defines and classifies the smart city service focusing on transportation and the components. The business model has been constructed for electric vehicles and autonomous shuttle businesses in terms of transportation services. It found that the model was profitable in each business only when various stakeholders were linked for mutual interests. Since various service stakeholders cooperate in smart city service, if one of them is unable to secure profitability, it is difficult to operate the smart city service fully. Therefore, a detailed review of the business model is required before providing a smart city service.
\end{abstract}

Keywords: smart city service; business model; smart city transportation service; urban planning

\section{Introduction}

Smart city services are major solutions for reducing costs and solving urban problems [1] by using information technology (IT) [2,3] for housing matters [4], traffic problems [5], and crime prevention [6] caused by rapid urbanization [7,8]. For this reason, the Smart city is becoming one of the most compelling tools for local governments who are seeking to meet sustainable development goals, achieve a higher quality of life for residents, improve government efficiency, and bring about collaborative governance [9]. In addition, smart cities can improve quality of life, save time, increase economic benefit, and consequentially maximize value by applying advanced technologies to cities [6]. With the development of smart cities, the services that are being provided in cities are also diversifying, and as many smart technologies are developed to provide services, the smart city-related industries and markets are also growing significantly [10]. The global smart cities market size expects a compound annual growth rate (CAGR) of $17.3 \%$ from 2020 to 2030 [11].

The previous studies on the success factors of smart cities mostly focused on analyzing the key factors in the field of technology and technical [12]. However, an examination of the types of smart city services that have been implemented revealed interesting points that include the construction of various smart city services. Some of them were unable to secure economic viability during the operating periods and consequently many of them failed or disappeared. This implies that smart city services need to secure economic profitability to be sustainable. Nevertheless, consequent to their strong tendency to solve urban problems in the pursuit of public interests, there is little concern about profitability, despite it being the most important objective for maintaining smart city services.

As the maintenance cost of smart city services in Canada, China, and the UK has increased rapidly compared to the profit structure, service providers are facing bankruptcy or even being sold [13]. Additionally, in Korea, in the case of early smart cities, the management and operation of smart cities and services after the construction of the city 
were lacking in consideration as they focused on the construction of cities that introduced new technologies and the provision of infrastructure. As a result, the profit structure of most smart cities was found to be weak [13]. Difficulties in the continuous profit structure may lead smart city services to be unsustainable. Furthermore, since local government has a role in local development, operation, and maintenance of public tasks, profit structure is crucial for local governments [14]. To implement smart cities services, local governments, funding from the central government, or other external funding is required, and if smart city services fail to realize profits, it remains as a local debt which will gradually increase since the maintenance. The issue of indebtedness of communes for local development is more critical in rural municipalities where the population is low [15]. Therefore, to overcome this, it is necessary to develop a new business model, and in particular, considering the profit structure. Furthermore, smart city services involve large-scale infrastructure investments, which would be recovered later through the service models [16]. Thus, given the largescale initial investment required, the projected profitability of smart city services must be thoroughly reviewed in advance of the startup and must be accurate.

In addition, considering that the competitiveness of the business model lies in a clear value proposition and a revenue mechanism [13], it is necessary to secure sustainability through a revenue model. Further, in the case of a profit model, not only economic profit but also social and environmental costs and profit streams, which are components of the Triple Bottom Line proposed by Osterwalder and Pigneur [17], can be included.

Therefore, in this study, we aim to propose a business model to secure the competitiveness of the smart city model after classifying the recently proposed smart city service types in Korea. This will help overcome the operational failures of smart cities and ensure sustainability. In Chapter 2, along with the definition of a smart city, major issues related to solving urban problems were divided into housing matters, traffic problems, and crime prevention, and the development status of Korea was analyzed. In Chapter 3, the business model of transportation service, which is an alternative to solving the traffic problem, which is the main cause of development, was investigated and analyzed in detail, since transportation services are being developed as the most basic infrastructure of smart cities along with energy services, and their proportion is increasing.

\section{Literature Review}

\subsection{Definition of Smart City}

The concept of smart city is still a subject of debate and varies across each country. In general, however, it means a concept that uses innovative digital technology to utilize urban service more efficiently [18]. Most of the developed country's goal of smart city is to regenerate the urban area or to increase the resilience for climate change adaptation and improve the quality of life of citizens, and most of the developing country's goal is to solve urban issues due to the rapid urbanization [19]. Smart cities use new and advanced technology to create a more sustainable urban environments and solve urban problems [20]. The various key elements other than only technology such as people, economy, governance, mobility, environment, and living connect and integrate with digital innovation [21].

\subsection{Urban Problems Related to the Core Needs of Smart Cities}

Smart cities consist of various services. However, the smart city services that were not profitable disappeared while those with profitability advanced further. Hence, it is necessary to examine and summarize the smart city services presented to solve urban problems. Urbanization is a worldwide phenomenon [22], and diverse smart city services include those developed to solve residential spatial and transportation problems.

Figure 1 shows that urbanization rates (1990-2018) have increased dramatically, whereas cities have limited space based on their size. A comparison of the urbanization rates and the growth rates of urban spaces in cities shows that the supply of urban spaces and residential environments [23] is not proportionate with the increasing population. 


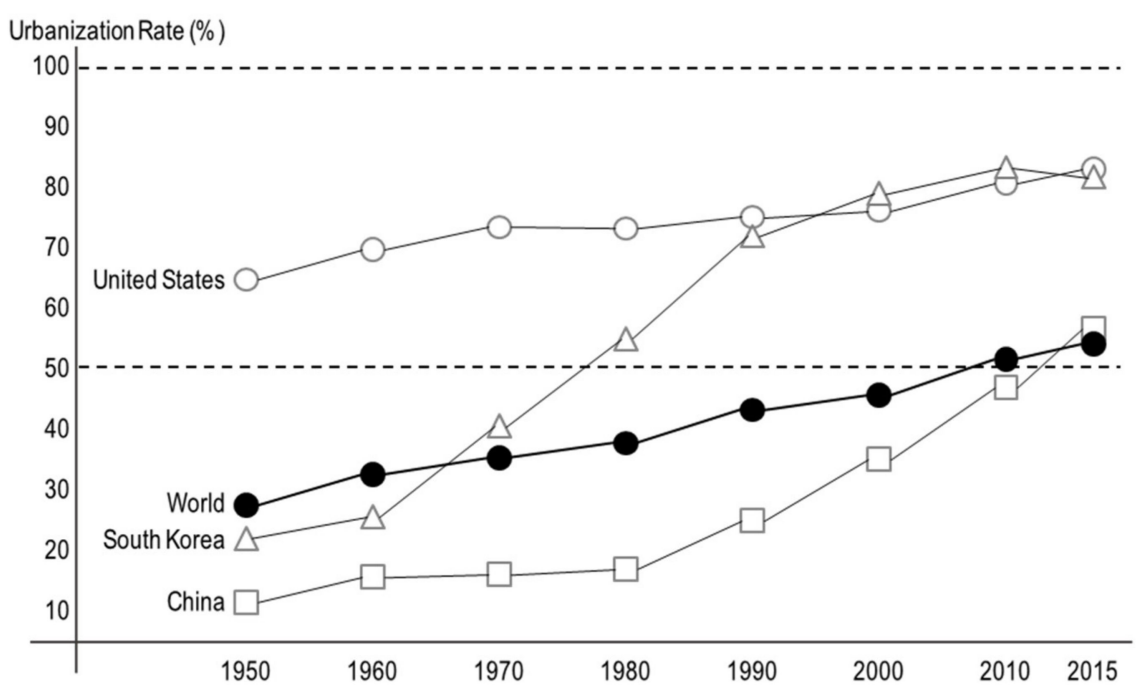

Figure 1. Urbanization rate and Urban Population (1950-2016) [24], table contents rearranged by the authors.

This is because the expansion rate of urban spaces has been unable to keep pace with the urban growth rate [25], and the rate of supplying living areas has been slower than the urban growth rate [26]. In other words, the major issue of urbanization is the lack of housing and space. Therefore, supplying additional housing and buildings should be continuous to solve the space scarcity problem. Simultaneously, the quality of residential and work environments should be continuously improved in line with the increase in urban density [27].

Smart city services focus on supplying large-scale entry-level housing to increase the efficiency of physical space expansion [28]. An example of building large-scale entrylevel houses is the use of the next-generation modular construction method [29,30], which involves stacking prefabricated standard spatial blocks (similar to Lego blocks). In addition to constructing buildings in a shorter period, it is also inexpensive [31]. Furthermore, smart homes and buildings which are the type of smart city services help to improve the quality of residential and work environments [32]. In short, a major perspective of smart city services is the need to resolve the housing and space problems. Various smart city solutions have been provided based on products, such as smart home electronics, smart lighting, and energy storage systems.

Rapid urbanization also creates problems in the methods of transportation. The major problems are increasing traffic accidents [33], increasing traffic congestion [34], and lack of parking spaces [35]. Smart mobility and transportation are a very important factors in smart cities [36]. Smart city services have been researched and introduced to solve these problems.

There are studies $[5,37]$ on the methods to reduce traffic accidents, including the implementation of smart city transportation services. Traffic accident types can be classified into vehicle-to-vehicle [38,39] and vehicle-to-pedestrian accidents [40,41]. To reduce vehicle-to-vehicle accidents, studies [42-44] have been conducted on the methods of sharing information between vehicles and surrounding traffic facilities, as well as between vehicles and a traffic integration center. Typical technologies include vehicle-to-everything communication (V2X) [45].

For the safety of pedestrians, studies [46,47] have mainly focused on the methods for preventing accidents, where pedestrians may get injured by vehicles. Specifically, South Korea is in the process of constructing a pedestrian-first traffic environment as a measure to reduce traffic accident deaths $[48,49]$. 
Additionally, studies $[50,51]$ to relieve traffic congestion have been conducted through the implementation of smart city transportation services. Traffic congestion occurs when the number of vehicles exceeds the capacity of the roads. However, there is a limit to physically increasing roads in the current urban structure. Therefore, smart city transportation services aim to relieve traffic congestion by controlling the movements and flow rates of vehicles on roads using a software approach. Typical technologies include Intelligent Transport Systems (ITS). This is where Information and Communication Technology (ICT) runs the role as an enabler for smart transportation [52]. Technology enables public and private mobility support systems and transportation sharing services including bike and car sharing [53].

Lastly, studies [54-57] have been conducted to solve the lack of parking spaces through the implementation of smart city transportation services. Since rapid urbanization has sharply increased the number of moving vehicles in the city, it necessitates a dramatic increase in parking spaces for vehicles. However, there are limitations to physically increasing parking spaces. Therefore, smart city services aim to solve the problem of insufficient parking spaces in cities through vehicle-shared services and vacant parking space connection services.

All these smart city transportation services must be profitable and sustainable since it is fundamental to social life and economy since it contributes to the quality of everyday life and ensure the equity and accessibility by smart solutions [58]. While the existing research literature includes many studies on the methods of implementing each service, very few studies have factored in the costs required to build and maintain these services, or summarized the business models for each service.

\section{Method}

Among the various smart city services that have been provided in South Korea, those that were not economically profitable failed, while services that secured profitability expanded their service models [13]. Smart city service for crime prevention and residential space problems which includes facility management and living service was found to be the highest proportion with $20 \%$, followed by medical treatment and transportation was $18.0 \%$ and $14.0 \%$, respectively in 2008 when the early smart city started (Table 1 ). After nine years, in 2017, transportation service became $30.3 \%$ which was the most frequent service used over all while crime prevention, residential space problems, and medical treatment has decreased to $24.2 \%, 15.2 \%$, and $3.0 \%$, respectively. Since the transportation service is a field with very high sensibility of citizens, there are many services that are technically feasible to commercialize, and the demands of local governments and citizens are always high [13]. Many smart city services for transportation including Bus Information System, which is also called Intelligent Transportation System, traffic management system, traffic information system, electronic vehicle charging, and smart tolling service is already very commonly used in many countries. Comparing to transportation service, the target user of service for residential space problem is not most of the public but specific residents or visitors, it has a limitation of profit. Further, crime prevention has an important role for society and recently it has been used frequently, however, the funding comes from the government since it is a social service more than a service for profit.

Therefore, this study focuses on transportation service which is the most frequently used service overall. To define and classify smart city transportation services, previous studies have been reviewed. According to each classification, the components of the smart city services on transportation service in South Korea, the United States, Japan, the EU, and China have been reviewed. These five countries are the countries that most actively introduce the Smart City services. Based on the transportation services, a business model has been constructed for each service to assess the profitability (Figure 2). 
Table 1. Changes in the application frequency and proportion for each smart city services ${ }^{1}$ (2008-2017) [59].

\begin{tabular}{ccccccccccc}
\hline Smart City Services & $\mathbf{2 0 0 8}$ & $\mathbf{2 0 0 9}$ & $\mathbf{2 0 1 0}$ & $\mathbf{2 0 1 1}$ & $\mathbf{2 0 1 2}$ & $\mathbf{2 0 1 3}$ & $\mathbf{2 0 1 4}$ & $\mathbf{2 0 1 5}$ & $\mathbf{2 0 1 6}$ & $\mathbf{2 0 1 7}$ \\
\hline Crime & $10(20.0)$ & $7(13.7)$ & $17(42.5)$ & $23(38.3)$ & $7(17.1)$ & $9(23.7)$ & $1(14.3)$ & $3(23.1)$ & $4(21.1)$ & $8(24.2)$ \\
prevention & $7(14.0)$ & $5(9.8)$ & $3(7.5)$ & $7(11.7)$ & $3(7.3)$ & $5(13.2)$ & $1(14.3)$ & $2(15.4)$ & $7(36.8)$ & $10(30.3)$ \\
Transportation & $4(8.0)$ & $0(0.0)$ & $0(0.0)$ & $6(10.0)$ & $6(14.6)$ & $1(2.6)$ & $0(0.0)$ & $1(7.7)$ & $0(0.0)$ & $0(0.0)$ \\
Governance & $5(10.0)$ & $10(19.6)$ & $3(7.5)$ & $7(11.7)$ & $3(7.3)$ & $2(5.3)$ & $3(42.9)$ & $1(7.7)$ & $0(0.0)$ & $5(15.2)$ \\
Environment & $6(12.0)$ & $3(5.9)$ & $3(7.5)$ & $2(3.3)$ & $2(4.9)$ & $5(13.2)$ & $1(14.3)$ & $2(15.4)$ & $1(5.3)$ & $2(6.1)$ \\
Facility & $9(18.0)$ & $9(17.6)$ & $5(12.5)$ & $2(3.3)$ & $3(7.3)$ & $5(13.2)$ & $1(14.3)$ & $2(15.4)$ & $2(10.5)$ & $1(3.0)$ \\
management & $2(4.0)$ & $5(9.8)$ & $4(10.0)$ & $2(3.3)$ & $6(14.6)$ & $3(7.9)$ & $0(0.0)$ & $1(7.7)$ & $0(0.0)$ & $3(9.1)$ \\
Medical & $0(0.0)$ & $2(3.69)$ & $1(2.5)$ & $2(3.3)$ & $1(2.4)$ & $1(2.6)$ & $0(0.0)$ & $0(0.0)$ & $0(0.0)$ & $0(0.0)$ \\
treatment & $2(4.0)$ & $2(3.9)$ & $1(2.5)$ & $1(1.7)$ & $3(7.3)$ & $2(5.3)$ & $0(0.0)$ & $0(0.0)$ & $1(5.3)$ & $1(3.0)$ \\
Culture & $1(2.0)$ & $1(2.0)$ & $1(2.5)$ & $2(3.3)$ & $3(7.3)$ & $2(5.3)$ & $0(0.0)$ & $1(7.7)$ & $0(0.0)$ & $0(0.0)$ \\
Working & $4(8.0)$ & $7(13.7)$ & $2(5.0)$ & $6(10.0)$ & $4(9.8)$ & $3(7.9)$ & $0(0.0)$ & $0(0.0)$ & $4(21.1)$ & $3(9.1)$ \\
Logistics & $50(100)$ & $51(100)$ & $40(100)$ & $60(100)$ & $41(100)$ & $38(100)$ & $7(100)$ & $13(100)$ & $19(100)$ & $33(100)$ \\
Education & \multicolumn{7}{c}{ Table contents rearranged by the authors. \% in ().} & &
\end{tabular}

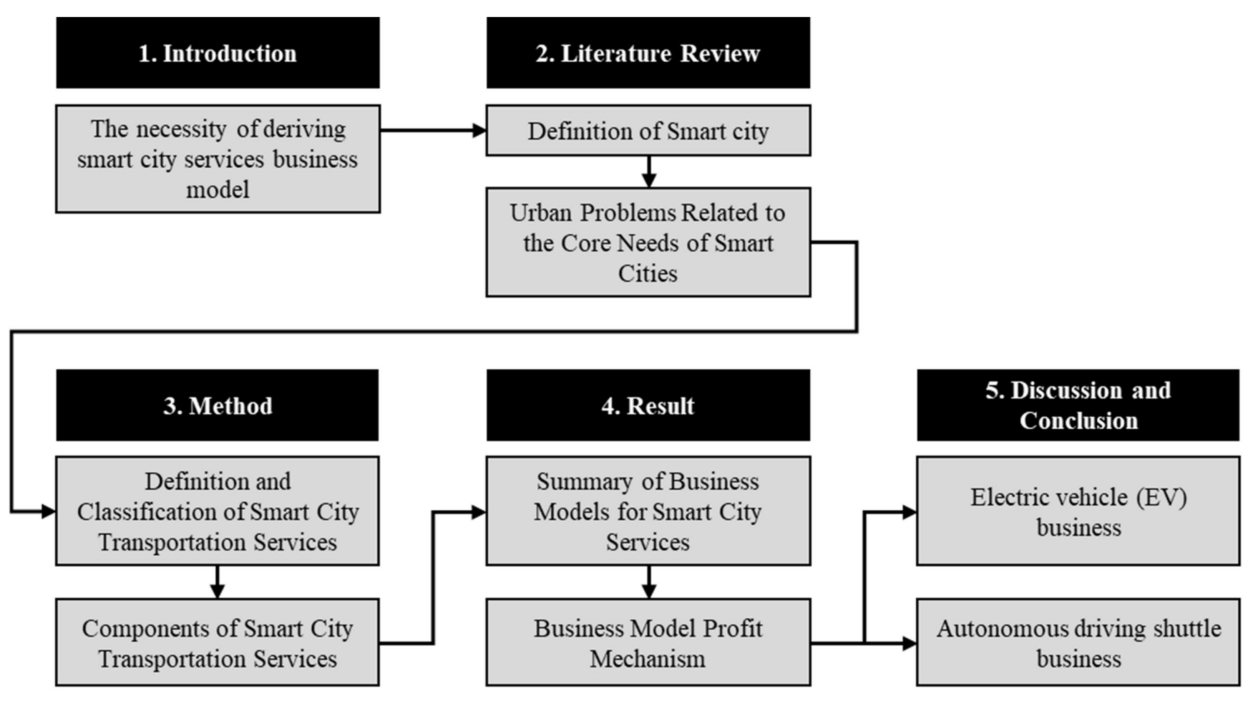

Figure 2. Flow of research.

\section{Result}

Crime prevention and transportation services are among the actively used smart city services as shown in Table 1. In other words, the core needs of smart city services are to solve urban crime and transportation problems. However, since crime prevention services are mostly public services [60], this study presents business models for transportation services. The business model of the public institutions (BSBM) is different from the business model of public sector. Goods and services provided by public institutions are often procured indirectly through redistribution of taxes, so they are likely to be considered 'free' [61]. In addition, since it provides products and services that meet the needs of general customers rather than specific customer groups, it has a stronger public nature than profitability. Therefore, this study intends to examine the business model of transportation services in detail.

\subsection{Definition and Classification of Smart City Transportation Services}

Smart city transportation service is a system of Location Based Services (LBS) and Geospatial Information System (GIS) focusing on the organic integration of telematics which has focused on the intellectualization and networking of vehicle domains, and ITS, which started with the intellectualization and networking of road/traffic systems. This is a new IT convergence technology that realizes an intelligent transportation system in connection with core technology. 
Mobility services comprise vehicle-oriented businesses, and many of their services are operational. According to the Act [62] on Promotion of the Transportation Convenience of Mobility Disadvantaged Persons, mobility services can be classified into three components: transportation safety, transportation convenience, and transportation operation (Table 2).

Table 2. Classifications of Transportation Services.

\begin{tabular}{|c|c|c|}
\hline \multicolumn{2}{|c|}{ Classifications } & Components \\
\hline \multirow[b]{2}{*}{$\begin{array}{l}\text { Transportation } \\
\text { safety }\end{array}$} & Intelligent vehicles & $\begin{array}{l}\text { Vehicle-to-Everything (V2X), Advanced Driver } \\
\text { Assistance Systems (ADAS) }\end{array}$ \\
\hline & $\begin{array}{l}\text { Infrastructure } \\
\text { informatization }\end{array}$ & $\begin{array}{l}\text { Intelligent Transport Systems (ITS), smart } \\
\text { pedestrian safety systems, Traffic management } \\
\text { control centers }\end{array}$ \\
\hline \multirow{2}{*}{$\begin{array}{l}\text { Transportation } \\
\text { convenience }\end{array}$} & $\begin{array}{l}\text { Information } \\
\text { distribution }\end{array}$ & Traffic information \\
\hline & Toll service & Smart tolling \\
\hline \multirow{2}{*}{$\begin{array}{l}\text { Transportation } \\
\text { operation }\end{array}$} & $\begin{array}{l}\text { Moving vehicle } \\
\text { operation }\end{array}$ & Autonomous driving shuttles, Freight transport \\
\hline & Facility operations & Shared services, Charging infrastructures \\
\hline
\end{tabular}

Transportation safety includes Intelligent vehicles and Infrastructure informatization. Intelligent vehicle includes Vehicle-to-Everything (V2X) and Advanced Driver Assistance System (ADAS) which promotes driving safety and prevents accident by intelligently recognizing driver behavior, driving conditions, and road conditions to predict possible accidental situations while driving. Infrastructure informatization includes Intelligent Transport Systems (ITS), smart pedestrian safety systems, and Traffic management control centers which provides information to control safety by integrating control system.

Transportation convenience provides an interface and driving environment to the driver based on biometric information or collected information from the control system to minimize the driving load. It also includes automated payment systems such as smart toll.

Transportation operation includes moving vehicles such as autonomous driving shuttle or freight transport and Facility operation such as shared services or charging infrastructure. This is a service in various business areas such as vehicle green ICT industry, logistics, $\mathrm{u}$-Home, insurance, transportation, medical care, national defense, etc. It is an industry that creates a new industry by inducing a synergistic effect between industries.

\subsection{Components of Smart City Transportation Services}

The derived components of the transportation services have important characteristics and trends. The components of the services currently operated in South Korea, the United States, Japan, the EU, and China are summarized in Table 3.

Each component requires infrastructure including networks, sensors, GPS, and power to operate. The city system that manages and controls transportation is a key component to collect and communicate with other services. Vehicle-to-Everything (V2X) and Intelligent Transport Systems (ITS) provides service for optimal driving conditions by using traffic information and Smart Tolling to reduce the traffic stopping for payment. Advanced Driver Assistance Systems (ADAS) is a key technology for Autonomous Driving Shuttle which also receives information from City Traffic Management Control Center. The components are all based on ICT and information from the city control center. In addition, charging infrastructure for an electric vehicle are also one of the necessary components. 
Table 3. Components of Transportation Services: Definitions and Examples.

\begin{tabular}{cl}
\hline \multicolumn{1}{c}{ Components } & \multicolumn{1}{c}{ Definitions } \\
\hline $\begin{array}{c}\text { Vehicle-to-Everything } \\
\text { (V2X) }\end{array}$ & $\begin{array}{l}\text { Vehicles exchange information using wired / wireless } \\
\text { networks, with other vehicles or objects, having } \\
\text { infrastructure, such as the construction of roads or } \\
\text { smart technology. }\end{array}$ \\
\hline $\begin{array}{c}\text { Advanced Driver } \\
\text { Assistance Systems } \\
\text { (ADAS) }\end{array}$ & $\begin{array}{l}\text { Using advanced detection sensors, GPS, } \\
\text { communication, intelligent video equipment, etc.; } \\
\text { while driving, the vehicle determines the situation } \\
\text { and controls itself, or the driver detects risk factors } \\
\text { in advance. }\end{array}$ \\
\hline $\begin{array}{l}\text { Intelligent Transport } \\
\text { Systems (ITS) }\end{array}$ & $\begin{array}{l}\text { The term Intelligent Transport Systems (ITS) refers } \\
\text { to efforts to collect, store and provide real-time } \\
\text { traffic information to maximize efficiency, provide } \\
\text { convenient safe transport, and reduce energy by } \\
\text { applying advanced electronics as well as } \\
\text { information and telecommunication technologies } \\
\text { into roads, automobiles, and goods. }\end{array}$ \\
&
\end{tabular}

\begin{tabular}{cl}
\hline A smart crosswalk construction service that provides \\
Safety System & $\begin{array}{l}\text { sensor-based pedestrian safety detection and voice } \\
\text { information services, encouraging the drivers to } \\
\text { slow down and stop at the stop-line. }\end{array}$
\end{tabular}

City Traffic
Management Control
Center

The entire city system relates to one communication network, where individual services (governance, transportation, crime prevention, disaster prevention, environment, underground utilities, etc.) are interlinked.
- In-vehicle navigation system

- $\quad$ Adaptive Cruise Control (ACC)

- $\quad$ Lane Departure Warning System (LDWS)
- $\quad$ Advanced Traffic Management System (ATMS)

- $\quad$ Advanced Traveler Information System (ATIS)

- $\quad$ Advanced Public Transportation System (APTS)

- $\quad$ Commercial Vehicle Operation (CVO)

- $\quad$ Advanced Vehicle and Highway System (AVHS)

- $\quad$ Ground light-emitting diode (LED) pedestrian signals

- Voice information devices for pedestrian signals

- $\quad$ Focused lighting

- Vehicle stop-line compliance monitoring system

- Integrated operation center

- Integrated operation platform Collecting and selling open data (traffic volume, Traffic information accident information, construction information) generated from traffic.

- National Traffic Information System (eNaTIS / NaTIS)

- $\quad$ Urban Traffic Information (UTIC)

Tolls are paid without stopping the vehicle by

Smart Tolling recognizing the terminal device or the license plate number.

\begin{tabular}{clll}
\hline $\begin{array}{c}\text { Autonomous Driving } \\
\text { Shuttle }\end{array}$ & $\begin{array}{l}\text { Cooperative automated driving-based public } \\
\text { transport vehicle operation. }\end{array}$ & $\begin{array}{l}\text { Bus autonomous driving } \\
\text { Taxi autonomous driving }\end{array}$ \\
\hline Freight Transport & $\begin{array}{l}\text { Cooperative automated driving-based large freight } \\
\text { vehicle operation. }\end{array}$ & $\bullet$ & Truck autonomous driving \\
\hline Shared Services & Services for sharing electric vehicles. & $\bullet$ & EV shared mobility \\
\hline $\begin{array}{c}\text { Charging } \\
\text { infrastructure }\end{array}$ & $\begin{array}{l}\text { Infrastructure and systems for electric } \\
\text { vehicle charging. }\end{array}$ & $\bullet$ & $\begin{array}{l}\text { Solar charge system } \\
\text { Energy Storage System (ESS) } \\
\text { Roof solar charging system }\end{array}$ \\
\hline
\end{tabular}

\subsection{Summary of Business Models for Smart City Services}

In Figure 3, Model 1 is the city traffic management, which consists of two main business models: road operation solution construction and traffic-associated facility construction. The business model of road operation solution construction and operation services comprises traffic situation control, toll payment, and vehicle sharing platforms, for 
which this business model's core competency is possessing a city-scale traffic management system. Additionally, the business model of the traffic-associated facility construction consists of smart streetlights, smart traffic lights, and smart stops. This business model's core competency is securing the line-up of traffic-associated facilities. However, it is difficult to secure profitability in the city traffic management because it requires huge investments to build large-scale infrastructure. Therefore, the government should implement it as a public service. Since this business model includes a public service, it was excluded from this study.

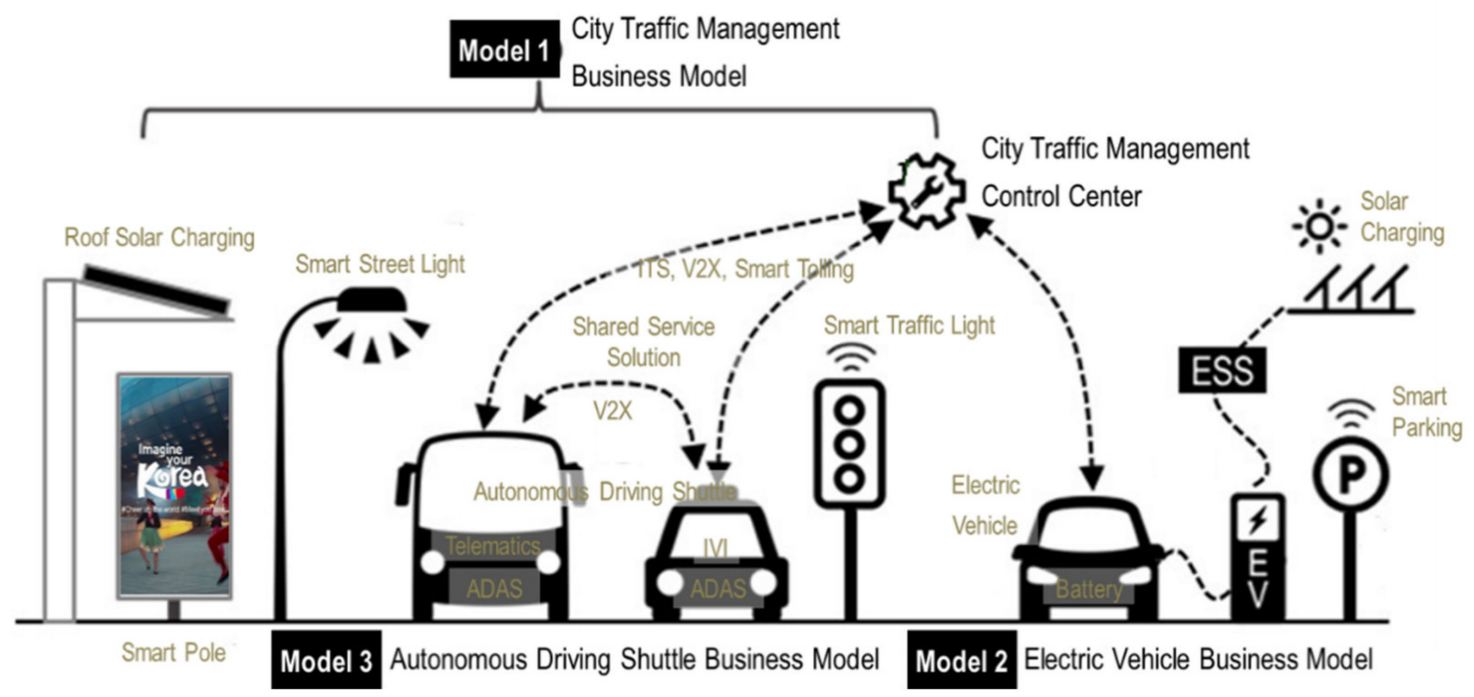

Figure 3. The summary of each service model of the smart city transportation services in terms of transportation safety, transportation convenience, and transportation operations.

Model 2 is for the electric vehicle (EV) business, whose two models comprise constructing and operating solutions for supplying and using electric components of EVs and operating EVs. The core competency of the business model is constructing and operating solutions for the supply and use of electric components of EVs and possessing a circulation system for supplying, collecting, and recycling batteries for EVs.

Model 3 is the autonomous driving shuttle business that operates autonomous public transportation vehicles by linking them with the traffic control system. The core competency of this business model is possessing a connected solution to control the movements of autonomous driving shuttles and public transport systems. Each business model is listed in Table 4.

The autonomous driving shuttle business model is highly related to city traffic management business model since it operates based on the information or control service. It provides transport service and In-Vehicle Infotainment (IVI) service to the user which is controlled by Traffic Management Control Center. It is also a part of the Electric Vehicle Business Model since it uses electric vehicles. Electric Vehicle Business Model uses the information from Traffic Management Control Center also to use smart parking and solar charging system. The City Traffic Management Business Model provides infrastructure and information for the other two business models and provides the optimal solutions for energy saving. These three business models are connected, and some components could be considered as a part of other business models.

Model 1 is entirely a public service model. Therefore, Model 1 is inappropriate for deriving a business model and excluded from this study. Model 2 is a private service and Model 3 comprises a combination of public and private services. This study analyzed the business model based on Model 2 and Model 3. 
Table 4. Classification and core competencies of business models for smart city transportation services.

\begin{tabular}{|c|c|c|c|}
\hline \multicolumn{2}{|c|}{$\begin{array}{l}\text { Business Model for Smart City } \\
\text { Transportation Services }\end{array}$} & $\begin{array}{c}\text { Core } \\
\text { Competencies }\end{array}$ & Remarks \\
\hline \multirow[t]{2}{*}{$\begin{array}{l}\text { Model } 1 \text {. City traffic } \\
\text { management business }\end{array}$} & $\begin{array}{l}\text { Construction and operation of road } \\
\text { operation solutions (traffic situation } \\
\text { control, toll payments, vehicle } \\
\text { sharing platforms) }\end{array}$ & $\begin{array}{l}\text { A city-scale traffic } \\
\text { operation system }\end{array}$ & \multirow[t]{2}{*}{ Public service } \\
\hline & $\begin{array}{l}\text { Construction of traffic facilities (smart } \\
\text { streetlights/traffic lights, smart stops) }\end{array}$ & $\begin{array}{l}\text { Securing a line-up of } \\
\text { traffic facilities }\end{array}$ & \\
\hline \multirow{2}{*}{$\begin{array}{l}\text { Model } 2 \text {. Electric } \\
\text { vehicle (EV) business }\end{array}$} & $\begin{array}{l}\text { Construction and operation of solutions } \\
\text { for supplying and using electric } \\
\text { components of EV }\end{array}$ & $\begin{array}{l}\text { EVs } \\
\text { Circulation system for supply- } \\
\text { ing/collecting/recycling batteries }\end{array}$ & \multirow[b]{2}{*}{ Private service } \\
\hline & $\begin{array}{l}\text { Construction and operation of EV } \\
\text { operating solutions (EV system, } \\
\text { renewable energy-combined charging, } \\
\text { smart parking) }\end{array}$ & Charging solutions & \\
\hline $\begin{array}{l}\text { Model 3. Autonomous } \\
\text { driving shuttle } \\
\text { business }\end{array}$ & $\begin{array}{l}\text { Construction and operation of a } \\
\text { combined package of autonomous } \\
\text { vehicles and traffic control system (Traffic } \\
\text { flow, unexpected situation control) }\end{array}$ & $\begin{array}{l}\text { Autonomous vehicles } \\
\text { Connected vehicle solutions } \\
\text { (telematics, In-Vehicle } \\
\text { Infotainment (IVI)) } \\
\text { Road traffic control solutions }\end{array}$ & $\begin{array}{l}\text { Public service }+ \\
\text { private service }\end{array}$ \\
\hline
\end{tabular}

\subsection{Business Model Profit Mechanism}

The structure and major constituents of private businesses for the EV business (Model 2) and the autonomous driving shuttle business (Model 3) are summarized in Figure 4 and Table 5.
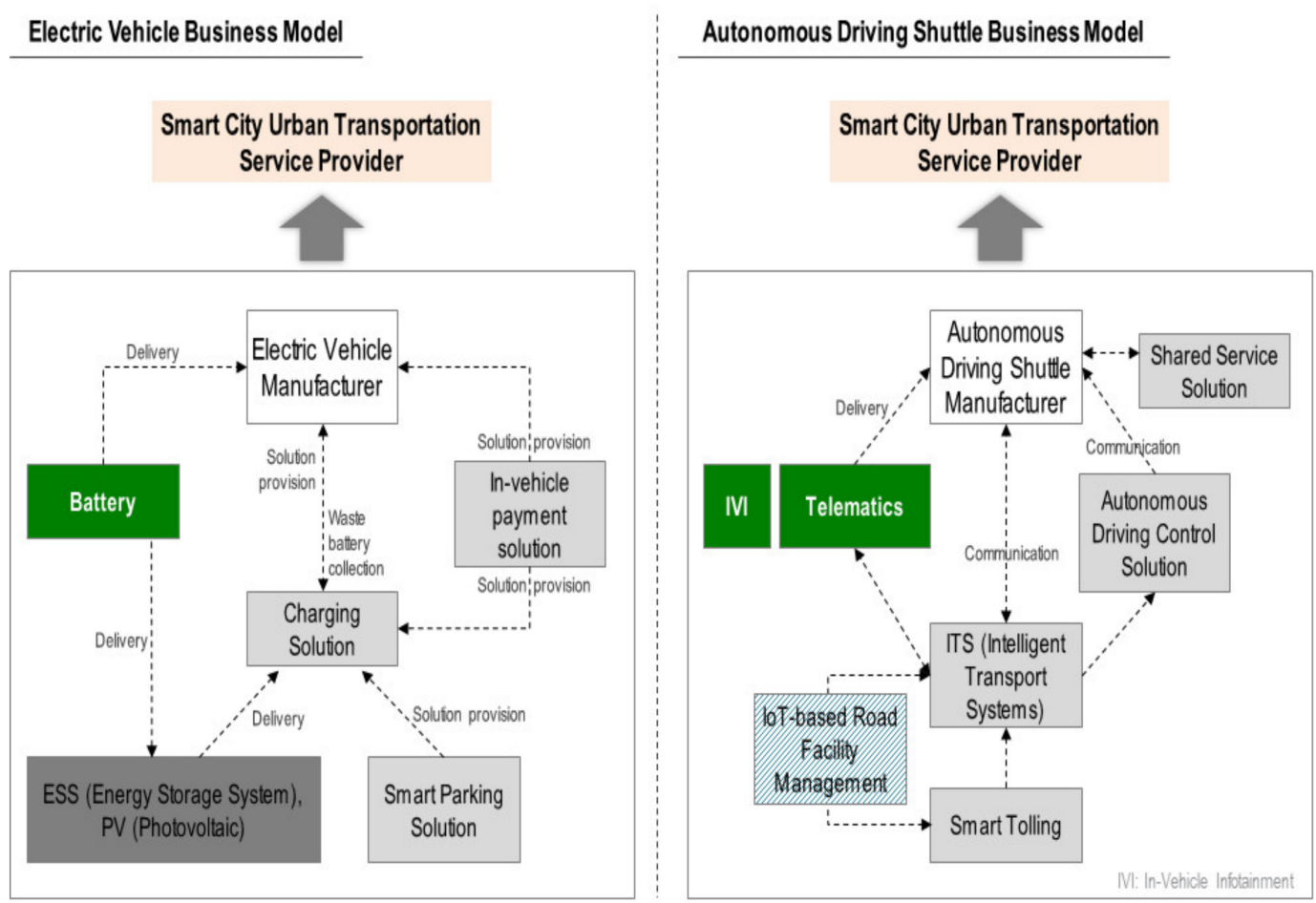

Figure 4. Business models of smart city transportation services. 
Table 5. Constituents of business models for smart city transportation services.

\begin{tabular}{ll}
\hline \multicolumn{2}{c}{ Constituents of the Business Models for Smart City Transportation Services } \\
\hline $\begin{array}{l}\text { Model 2: Electric vehicle } \\
\text { (EV) business }\end{array}$ & $\begin{array}{l}\text { Consists of manufacturers of vehicles, and providers of parts, } \\
\text { products, and solutions. }\end{array}$ \\
\hline $\begin{array}{l}\text { Model 3: Autonomous } \\
\text { driving shuttle business }\end{array}$ & $\begin{array}{l}\text { Consists of public services-Intelligent Transport Systems, } \\
\text { autonomous driving, part manufacturers, solution providers, and } \\
\text { service providers. }\end{array}$ \\
\hline
\end{tabular}

The summary of the profit model of each private business operator revealed that EV manufacturers, who were the center of the EV business model, needed companies to provide parts—batteries, products-ESS and photovoltaics, and solutions-charging, smart parking, and in-vehicle payment solutions. In other words, the EV business model consists of EV manufacturers, along with part, product, and solution providers. The main profit model of each specialized company is supplying parts/products or providing solutions to the EV manufacturers. However, generating revenue through parts/products is also a profit model for general internal combustion engine car developers. Therefore, the key source of revenue for electric vehicles is solutions. For example, Tesla's commonly known business model is the charging of electric vehicle charging systems. In other words, it is a profit model through the brokerage of electric energy rather than vehicle sales. To this end, Tesla has disclosed various patents related to electric vehicle charging systems. Through this, it is possible to secure profits by preempting the standards and infrastructure for electric vehicle charging and allowing electric vehicles other than Tesla to adopt and use this charging system. As the user has to pay for the lifetime of charging an electric vehicle as long as the user uses the vehicle, such as the fuel cost of a general vehicle and the communication cost of a smartphone, it can dominate the electric energy market larger than vehicle sales by establishing standards and infrastructure for this.

At the center of the autonomous driving shuttle business model is the autonomous driving shuttle manufacturers, who require companies that provide parts-In-Vehicle Infotainment (IVI), telematics, solutions-shared services and autonomous driving control solutions, ITS, and smart tolling, and services-Internet of things-based road facility management. In other words, the autonomous driving shuttle business model consists of parts, solutions, and service companies; the main profit model of each specialized company is supplying parts/products or providing solutions to the autonomous driving shuttle manufacturers. Figure 4 illustrates the schematics of each business model.

An autonomous driving control solution gave the users extra time when they commute and extra space in the car as the steering wheel and other parts are not necessary anymore. Ford developed an Autonomous Vehicle Entertainment System which uses the vehicle as a theater while the car is driving autonomously, and Volvo and Toyota developed cars that can tilt the seats during the car drive autonomously to use the space as an office, entertainment, or sleeping space. The startup Robomart is designing an on-demand autonomous driving vehicle with a transparent display on one side to deliver food or grocery. Autonomous driving technology will generate Passenger Economy which is the economic and social value when fully autonomous vehicles can generate will be worth 7 trillion US dollars in 2050 [63]. This includes consumer mobility, B2B mobility, charging service, and autonomous driving solutions.

\section{Discussion and Conclusions}

Smart cities are presented around the world as a major solution for solving urban problems. However, it is difficult to operate smart city service models continuously, unless operating profits are secured. The number of newly introduced smart city service models has been increasing dramatically because of advances in technology. However, an analysis of past cases shows that among countless smart city services, those that are still under operation have decreased. In other words, the business model of each smart city 
service must be reviewed and validated in advance to secure the continuity of smart city service models.

Transportation services were found to be the most important, after classifying recently proposed smart city service models. The components of transportation services are divided into safety, convenience, and operations. This study reclassified the components for the $\mathrm{EV}$ and autonomous driving shuttle businesses of the transportation operation, and the business models were constructed at a basic level. Thus, it was found that in each business, various stakeholders relate to each other for mutual interests in a single profitable model.

Various stakeholders cooperate to build a smart city service. Therefore, if even one of the various stakeholders constituting a service does not secure economic profitability, it would be difficult to operate the smart city service fully. In other words, a detailed review of the business model is required in advance, to operate a smart city service stably and continuously. This study has focused on smart city service on transportation section and its business model. Many cities and local governments introduce smart city services. However, maintaining the service is challenging due to the profitability since the fundamental infrastructure and maintenance require a large amount of finance. Previously, implementation of a smart city service considered mostly how to introduce the technology to service. However, while smart city service is commonly implementing, maintenance and sustainability are becoming the issue both financially and environmentally. A proper business model suggested for transportation service would provide a sustainable mechanism of transportation service and smart city.

Various advanced technologies are being developed through technological innovation. However, in the process of commercialization of these technologies, commercialization failure occurs due to the absence of an appropriate business model. Technological innovation is creating fundamental changes in human life in various fields that have not been previously expected, which is also applied to smart cities, improving the living environment of city citizens and enabling sustainable development. In order for these technologies to be continuously applied to city operations, it is very important to develop and apply appropriate business models to sustain profitability.

Nevertheless, this study also had some limitations. Since the components of business models were minimized, the sizes of the elements constituting profitability were limited to the major stakeholders, such as motorized transportation for people. Since these components are the most developed technologies which are in use and commercialized, the needs by users and municipal are high and most of the local government has implemented these services. However, non-motorized transport and freight transport is also being developed and have high needs by local government and industries. Non-motorized transport is one of the commonly implemented smart transportation services to provide equity of accessibility and sustainable transportation, and freight transport is an innovative technology to reduce the cost of transportation. Hence, the components should be subdivided further, to examine the actual business models of smart city services in a more sophisticated manner. Moreover, future studies should subdivide the business models further to examine their profitability structure. The types of smart city services differ among countries and cities. However, this study simplified the service models. It used the components of South Korean smart cities that did not incorporate all the service types existing in different counties and cities. Therefore, based on the business models presented in this study, more appropriate business models should be developed for various types of smart city services. In addition, this study did not analyze the profitability of public services among the smart city services. In smart cities, public services that solve urban problems are significant. Furthermore, since large-scale construction and operation costs are injected into public services, their profitability analysis is important. Therefore, future studies should also analyze public services such as Model 1 (City traffic management business). 
Author Contributions: Conceptualization, J.K. and B.Y.; methodology, J.K.; validation, B.Y.; formal analysis, J.K.; investigation, J.K. and B.Y.; resources, J.K.; writing—original draft preparation, J.K.; writing-review and editing, B.Y.; visualization, J.K.; supervision, B.Y.; project administration, J.K. and B.Y.; funding acquisition, J.K. and B.Y. All authors have read and agreed to the published version of the manuscript.

Funding: This work is supported by the Korea Agency for Infrastructure Technology Advancement (KAIA) grant funded by the Ministry of Land, Infrastructure and Transport (Grant 21DEAPB158906-02).

Institutional Review Board Statement: Not applicable.

Informed Consent Statement: Not applicable.

Conflicts of Interest: The authors declare no conflict of interest.

\section{References}

1. Marchiori, M. The Smart Cheap City: Efficient Waste Management on a Budget. In Proceedings of the 2017 IEEE 19th International Conference on High Performance Computing and Communications;IEEE 15th International Conference on Smart City; IEEE 3rd International Conference on Data Science and Systems (HPCC/SmartCity/DSS), Bangkok, Thailand, 18-20 December 2017; pp. 192-199.

2. Kogan, N. Exploratory research on success factors and challenges of Smart City Projects Exploratory research on success factors and challenges of Smart City Projects. Asia Pac. J. Inf. Syst. 2014, 24, 141-189.

3. Morozov, E.; Bria, F. Rethinking the Smart City—Democratizing Urban Technology; Rosa Luxemburg Stiftung: New York, NY, USA, 2018; pp. 1-56.

4. Bisello, A. Assessing Multiple Benefits of Housing Regeneration and Smart City Development: The European Project SINFONIA. Sustainability 2020, 12, 8038. [CrossRef]

5. Rizwan, P.; Suresh, K.; Babu, M.R. Real-time smart traffic management system for smart cities by using Internet of Things and big data. In Proceedings of the 2016 International Conference on Emerging Technological Trends (ICETT), Kollam, India, 21-22 October 2016; pp. 1-7.

6. Park, M.S.; Lee, H. Smart city crime prevention services: The incheon free economic zone case. Sustainability 2020, $12,5658$. [CrossRef]

7. Bodo, T. Rapid Urbanisation: Theories, Causes, Consequences and Coping Strategies. Ann. Geogr. Stud. 2019, 2, 32-45.

8. Williams, D.S.; Máñez Costa, M.; Sutherland, C.; Celliers, L.; Scheffran, J. Vulnerability of informal settlements in the context of rapid urbanization and climate change. Environ. Urban. 2019, 31, 157-176. [CrossRef]

9. Myeong, S.; Kim, Y.; Ahn, M.J. Smart City Strategies-Technology Push or Culture Pull? A Case Study Exploration of Gimpo and Namyangju, South Korea. Smart Cities 2020, 4, 41-53. [CrossRef]

10. MOLIT. In Smart City National Pilot City; Ministry of Land, Infrastructure and Transportation: Sejong, Korea, 2019.

11. ACCESSWIRE The Global Smart Cities Market is Expected to Reach $\$ 4,269.3$ Billion by 2030 with a CAGR of $17.3 \%$. Available online: https: / www.bloomberg.com/press-releases/2021-02-15/the-global-smart-cities-market-is-expected-to-reach-4-2693-billion-by-2030-with-a-cagr-of-17-3 (accessed on 17 July 2021).

12. Myeong, S.; Jung, Y.; Lee, E. A study on determinant factors in smart city development: An analytic hierarchy process analysis. Sustainability 2018, 10, 2606. [CrossRef]

13. Song, Y.; Park, S.; Moon, B. Business model for sustainable smart city service; Architecture and Urban Research Institute: Sejong, Korea, 2020.

14. Anthopoulos, L.G.; Fitsilis, P. Smart cities and their roles in city competition: A classification. Int. J. Electron. Gov. Res. 2014, 10, 63-77. [CrossRef]

15. Kozera, A.; Standar, A.; Satoła, Ł. Managing rural areas in the context of the growing debt of polish local government units. Agric. 2020, 10, 376. [CrossRef]

16. Skowron, J.; Flynn, M. The challenge of paying for smart cities projects; Deloitte: London, UK, 2018; pp. 1-18.

17. Osterwalder, A.; Pigneur, Y. Usiness Model Generation: A Handbook for Visionaries, Game Changers, and Challengers; John Wiley \& Sons, Ltd.: Hoboken, NJ, USA, 2010; ISBN 0470876417/9780470876411.

18. OECD. Smart Cities and Inclusive Growth; OECD: Paris, France, 2020.

19. DaeYeon, C. Smart city and urban innovation. J. Comput. Sci. Eng. 2018, 36, 21-30.

20. Bakıc1, T.; Almirall, E.; Wareham, J. A Smart City Initiative: The Case of Barcelona. J. Knowl. Econ. 2013, 4, 135-148. [CrossRef]

21. Kirimtat, A.; Krejcar, O.; Kertesz, A.; Tasgetiren, M.F. Future Trends and Current State of Smart City Concepts: A Survey. IEEE Access 2020, 8, 86448-86467. [CrossRef]

22. UN. World Population Prospects 2019; United Nations: New York, NY, USA, 2019; ISBN 9789211483161.

23. Doytsher, Y.; Kelly, P.; Khouri, R.; McLaren, R.; Mueller, H.; Potsiou, C. Rapid urbanization and mega cities: The need for spatial information management. In Proceedings of the FIG Congress 2010, Sydney, Australia, 11-16 April 2010; pp. 1-25. 
24. UN World Urbanization Prospects-Population Division. Available online: https://population.un.org/wup/Download/ (accessed on 19 July 2021).

25. Ritchie, H.; Roser, M. Urbanization. Available online: https:/ / ourworldindata.org/urbanization (accessed on 23 September 2021).

26. Cohen, B. Urbanization in developing countries: Current trends, future projections, and key challenges for sustainability. Technol. Soc. 2006, 28, 63-80. [CrossRef]

27. Oh, J. Smart city as a tool of citizen-oriented urban regeneration: Framework of preliminary evaluation and its application. Sustainability 2020, 12, 6874. [CrossRef]

28. Colistra, J. Innovations in Housing for Smart Cities. J. Archit. Eng. 2019, 25, 06019001. [CrossRef]

29. Qi, B.; Costin, A.; Razkenari, M. Challenges of Implementing Emerging Technologies in Residential Modular Construction. In Proceedings of the CIB World Building Congress, Hong Kong, China, 17-20 June 2019; pp. 17-21.

30. Connected World Modular Construction and Smart Cities. Available online: https:// connectedworld.com/modular-constructionand-smart-cities / (accessed on 4 June 2021).

31. Nazir, F.A.; Edwards, D.J.; Shelbourn, M.; Martek, I.; Thwala, W.D.D.; El-Gohary, H. Comparison of modular and traditional UK housing construction: A bibliometric analysis. J. Eng. Des. Technol. 2021, 19, 164-186. [CrossRef]

32. Neirotti, P.; De Marco, A.; Cagliano, A.C.; Mangano, G.; Scorrano, F. Current trends in Smart City initiatives: Some stylised facts. Cities 2014, 38, 25-36. [CrossRef]

33. Fang, A.; Qiu, C.; Zhao, L.; Jin, Y. Driver Risk Assessment Using Traffic Violation and Accident Data by Machine Learning Approaches. In Proceedings of the 2018 3rd IEEE International Conference on Intelligent Transportation Engineering (ICITE), Singapore, 3-5 September 2018; pp. 291-295.

34. Han, F.; Xie, R.; Lai, M. Traffic density, congestion externalities, and urbanization in China. Spat. Econ. Anal. 2018, 13, 400-421. [CrossRef]

35. Kabisch, N.; van den Bosch, M.; Lafortezza, R. The health benefits of nature-based solutions to urbanization challenges for children and the elderly-A systematic review. Environ. Res. 2017, 159, 362-373. [CrossRef]

36. Aletà, N.B.; Alonso, C.M.; Ruiz, R.M.A. Smart Mobility and Smart Environment in the Spanish cities. Transp. Res. Procedia 2017, 24, 163-170. [CrossRef]

37. Shin, H.; Lee, J. Temporal Impulse of Traffic Accidents in South Korea. IEEE Access 2020, 8, 38380-38390. [CrossRef]

38. Mizui, K.; Uchida, M.; Nakagawa, M. Vehicle-to-vehicle communications and ranging system using spread spectrum techniques. Electron. Commun. Jpn. Part I Commun. (Engl. Transl. Denshi Tsushin Gakkai Ronbunshi) 1996, 79, 106-115. [CrossRef]

39. Ibanez-Guzman, J.; Lefevre, S.; Mokkadem, A.; Rodhaim, S. Vehicle to vehicle communications applied to road intersection safety, field results. In Proceedings of the 13th International IEEE Conference on Intelligent Transportation Systems, Funchal, Portugal, 19-22 September 2010; pp. 192-197.

40. Tahmasbi-Sarvestani, A.; Nourkhiz Mahjoub, H.; Fallah, Y.P.; Moradi-Pari, E.; Abuchaar, O. Implementation and Evaluation of a Cooperative Vehicle-to-Pedestrian Safety Application. IEEE Intell. Transp. Syst. Mag. 2017, 9, 62-75. [CrossRef]

41. Sewalkar, P.; Seitz, J. Vehicle-to-Pedestrian Communication for Vulnerable Road Users: Survey, Design Considerations, and Challenges. Sensors 2019, 19, 358. [CrossRef] [PubMed]

42. Putra, A.S.; Warnars, H.L.H.S. Intelligent Traffic Monitoring System (ITMS) for Smart City Based on IoT Monitoring. In Proceedings of the 2018 Indonesian Association for Pattern Recognition International Conference (INAPR), Tangerang, Indonesia, 7-8 September 2018; pp. 161-165.

43. Chun, B.T.; Lee, S.H. A study on intelligent traffic system related with smart city. Int. J. Smart Home 2015, 9, 223-230. [CrossRef]

44. Latif, S.; Afzaal, H.; Zafar, N.A. Intelligent traffic monitoring and guidance system for smart city. In Proceedings of the 2018 International Conference on Computing, Mathematics and Engineering Technologies (iCoMET), Sukkur, Pakistan, 3-4 March 2018; pp. 1-6.

45. Iqbal, Z.; Khan, M.I. Automatic incident detection in smart city using multiple traffic flow parameters via V2X communication. Int. J. Distrib. Sens. Netw. 2018, 14, 1550147718815845. [CrossRef]

46. Ali Muthanna, M.S.; Lyachek, Y.T.; Obadi Musaeed, A.M.; Ahmed Hazzaa Esmail, Y.; Adam, A.B.M. Smart System of a Real-Time Pedestrian Detection for Smart City. In Proceedings of the 2020 IEEE Conference of Russian Young Researchers in Electrical and Electronic Engineering (EIConRus), Moscow, Russia, 27-30 January 2020; pp. 45-50.

47. Arena, F.; Pau, G.; Severino, A. V2X Communications Applied to Safety of Pedestrians and Vehicles. J. Sens. Actuator Netw. 2020, 9, 3. [CrossRef]

48. Lee, H.; Kim, S.-N. Perceived Safety and Pedestrian Performance in Pedestrian Priority Streets (PPSs) in Seoul, Korea: A Virtual Reality Experiment and Trace Mapping. Int. J. Environ. Res. Public Health 2021, 18, 2501. [CrossRef]

49. Lee, S.; Lee, M.-H. Impact of Neighborhood Environment on Pedestrian Route Selection among Elementary Schoolchildren in Korea. Int. J. Environ. Res. Public Health 2021, 18, 7049. [CrossRef]

50. Torre, T.; Braccini, A.M.; Spinelli, R. Smart Mobility in Smart City. In Empowering Organizations; Torre, T.; Braccini, A.M.; Spinelli, R. Springer International Publishing: New York, NY, USA, 2016; pp. 13-28.

51. Jabbarpour, M.R.; Nabaei, A.; Zarrabi, H. Intelligent Guardrails: An IoT Application for Vehicle Traffic Congestion Reduction in Smart City. In Proceedings of the 2016 IEEE International Conference on Internet of Things (iThings) and IEEE Green Computing and Communications (GreenCom) and IEEE Cyber, Physical and Social Computing (CPSCom) and IEEE Smart Data (SmartData), Chengdu, China, 15-18 December 2016; pp. 7-13. 
52. Dameri, R.P. Erratum to: Smart City Implementation; Springer: New York, NY, USA, 2017; ISBN 9783319457659.

53. Garau, C.; Masala, F.; Pinna, F. Cagliari and smart urban mobility: Analysis and comparison. Cities 2016, 56, 35-46. [CrossRef]

54. Bignami, D.F.; Colorni, A.; Lu, A.; Nocerino, R.; Rossi, M.; Savaresi, S.M. Electric Vehicle Sharing Services for Smarter Cities; Springer: Cham, Switzerland, 2017; p. 280. [CrossRef]

55. Šilar, J.; Růžička, J.; Bělinovà, Z.; Langr, M.; Hlubučková, K. Smart parking in the smart city application. In Proceedings of the 2018 Smart City Symposium Prague (SCSP), Prague, Czech Republic, 24-25 May 2018; pp. 1-5.

56. Khanna, A.; Anand, R. IoT based smart parking system. In Proceedings of the 2016 International Conference on Internet of Things and Applications (IOTA), Pune, India, 22-24 January 2016; pp. 266-270.

57. Shaheen, S.A.; Mallery, M.A.; Kingsley, K.J. Personal vehicle sharing services in North America. Res. Transp. Bus. Manag. 2012, 3 , 71-81. [CrossRef]

58. Bakogiannis, E.; Siti, M.; Tsigdinos, S.; Christodoulopoulou, G.; Karolemeas, C. The challenge of smart mobility integration in the evolving smart city context; the paradigm of heraklion. In Proceedings of the 5 th International Conference on Connected Smart Cities (CSC), Porto, Portugal, 17-19 July 2019; pp. 217-225. [CrossRef]

59. Kim, M.; Jung, S. Current Trend of Smart City Service Application in Korea. Korea Contests Assoc. 2019, 19, 194-203. [CrossRef]

60. Patel, M.; Padhya, H. A Smart City Development Concept: The Songdo Experiences. Int. J. Res. Eng. Sci. 2021, 9, 7-10.

61. Lewandowski, M.; Kożuch, B.; Lewandowski, M. Public Sector Entrepreneurship and the Integration of Innovative Business Models; Advances in Public Policy and Administration; IGI Global: Hershey, PA, USA, 2017.

62. MOLIT. Improve Mobility for the Transportation-Disabled; Ministry of Land, Infrastructure and Transportation: Sejong, Korea, 2021.

63. Lanctot, R. Accelerating the Future: The Economic Impact of the Emerging Passenger Economy Autonomous; Strategy Analytics: Boston, MA, USA, 2017. 